(RESEARCH ARTICLE)

\title{
Poverty level of farmers based on total income and feasibility of rice farming
}

\author{
Jumiyati Sri * \\ Department of Agriculture Social Economics/Agribusiness, Faculty of Agriculture, Muhammadiyah University, Palu, \\ 94118 Central Sulawesi, Indonesia.
}

Publication history: Received on 25 November 2019; revised on 15 December 2019; accepted on 17 December 2019

Article DOI: https://doi.org/10.30574/wjarr.2019.4.2.0094

\begin{abstract}
Poverty is a persistent problem in Indonesia, especially in rural areas. The poor population in rural areas by their livelihood as farmers, and 75\% of the poor farmers are food crop farmers, especially rice farmers. The purpose of this study is to analyze the income and feasibility of farming and the poverty level of rice farmer household. This research was conducted in an area where most of the population is rice farmers. This study uses a qualitative descriptive method by analyzing quantitative data through income analysis and farm feasibility and poverty rates of farm household according to Sayogyo. Research shows that rice farming produces $1,845 \mathrm{~kg}$ with an income of IDR. 16,605,000 based on local rice prices, IDR. 9,000/kg. While the total costs incurred by farmers are IDR. 3,596,000 so that the household income of rice farmers is IDR. 13,009,000/year with an R/C value of 1.3. Based on the value of the household income of rice farmers with an average number of family dependents of 5 people, it can be determined the poverty level criteria that are equivalent to the level of rice consumption that is equal to $289.1 \mathrm{~kg} /$ person/year. Thus, rice farming households according to Sayogyo are in the criteria between "Very Poor" and "Poor" household with household income equivalent to $240-320 \mathrm{~kg}$ of rice/person/year. Because it has a feasibility value of more than 1, the rice farming has a comparative advantage, but the feasibility value has not been able to alleviate the rice farmer household of poverty.
\end{abstract}

Keywords: Land area; Income; Feasibility; Poverty level

\section{Introduction}

Currently, almost all countries in the world set a development policy agenda that generally includes dimensions of poverty alleviation, improving the quality of life and community empowerment that refers to the Sustainable Development Goals (SDGs) and the Millennium Development Goals (MDGs) to measure aspects and indicators of progress in development to effectively fight poverty [1].

The problem of poverty must be understood as a world problem, so it must be addressed in a global context. Poverty is a human development problem in developing countries, and poverty is an ongoing problem in Indonesia. Until the end of the 20th century poverty remained a global burden that had to be faced together in the SDGs era, which was triggered to continue and strengthen the achievement of the MDGs goals to be sustainable [2.3.4].

Economic growth and poverty are important indicators for the success of a country's development [5]. Based on the 2017 UN Food and Agriculture Organization report, economic growth and population dynamics drive structural changes [6]. Poverty is a multidimensional structural problem because of its relationship with the ability to access, economically, socially, culturally, and political participation in society [7.8]. Household living standards open the way for a deeper analysis of the nature and extent of poverty [9]. Based on the 2012 World Development Index which is a re-evaluation of the "\$ 1 per day" poverty line. According to the World Bank since 1999, the international poverty line has been recalibrated at $\$ 1.25$ per day based on purchasing power parity [10].

\footnotetext{
${ }^{*}$ Corresponding author

E-mail address: srijumiyati1068@gmail.com
} 
Poverty has long been a problem of the people of Indonesia, where until now there has been no sign of ending. The economic crisis in 1997 has resulted in a decline in Indonesia's economic growth. Even as a result of the ongoing crisis the Indonesian economy in the next two years got worse with minus growth. In 1998, each was $13.13 \%$ and 1999 was $-1.29 \%$. Various efforts to reduce poverty, continuously carried out by the Indonesian government through quality economic growth and increased access to basic needs [11].

Based on the results of the National Socio-Economic Survey (Susenas) conducted by the Central Statistics Agency (BPS), the number of Indonesians living below the poverty line was still quite large, in 2016 the poor population was recorded at 28.01 million (10.86\%), in 2017 there were 27.77 million $(10.64 \%)$ and 25.95 million people $(9.82 \%)$ in 2018 . The conditions of those living in poverty generally suffer from malnutrition, poor health, high illiteracy, poor environment and lack of access to adequate infrastructure and public services [12].

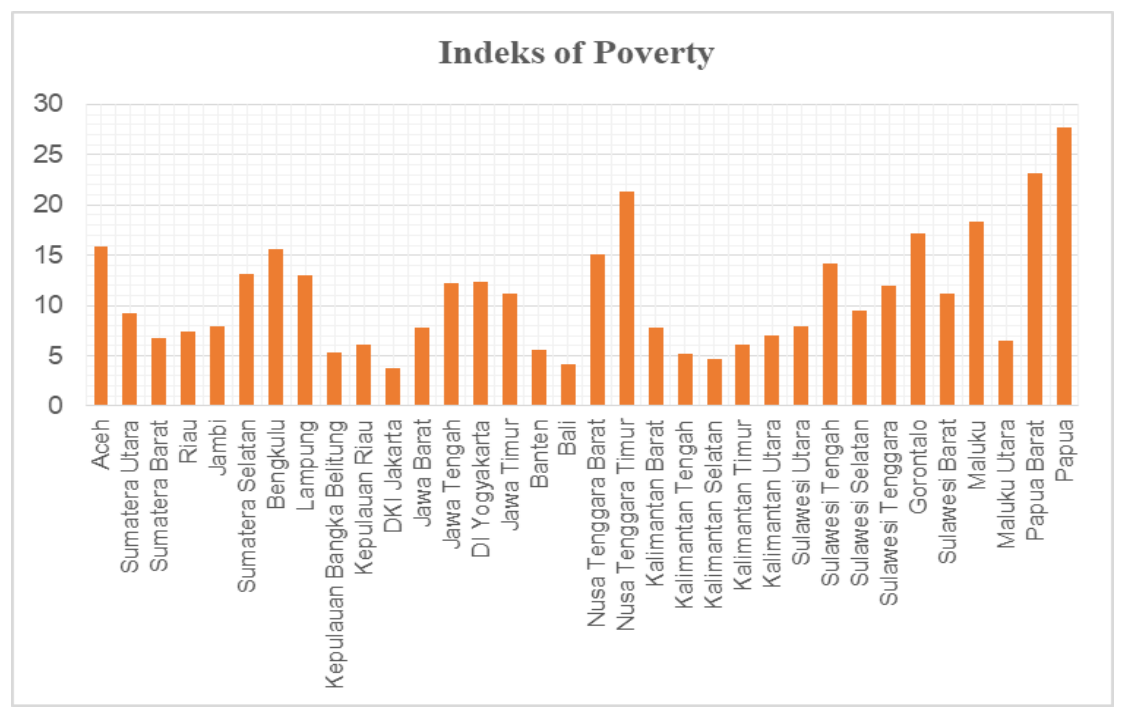

Figure 1 Index of poverty in Indonesia year 2017 (BPS)

Furthermore, out of 25.95 million poor people (9.82\%) of the total population of Indonesia, more than $13.20 \%$ of the poor are in rural areas, and are generally involved or related to the agricultural sector, and $75 \%$ of poor farmers are crop farmers, especially rice farmers [13]. The growth of agriculture in rural areas still plays a major role in reducing poverty, at the same time rural agriculture is also the largest contributor to poverty in the agricultural sector. There is a relationship between rural and poverty, and the agricultural sector can play a role in rural development and poverty reduction. Under certain conditions territorial/regional development strategies can be successful, but in other conditions, especially in countries that prioritize rural development, agriculture must remain a starting point for rural development [14].

The contribution of a sector to poverty alleviation is shown by its own growth performance, its indirect impact on growth in other sectors, the extent to which the poor participate in the sector, and the size of the sector in the economy as a whole. Improving the agricultural sector is a potential way to reduce rural poverty. By improving the rural livelihoods economy and changing rural agrarian societies see their agricultural business as one of the socio-economic development goals [15].

Rice farmers are the backbone that sets national food security targets. Although the goal of achieving national food security is the main agenda, it is important to understand the status of the livelihoods of rice farmers, especially their socioeconomic status related to their ability to achieve a minimum cost of living [16]. When the poverty line is a function of average income, the elasticity of the poverty line with respect to income plays an important role in determining the size of change due to growth [17].

To measure poverty, BPS uses the concept of ability to meet basic needs (basic needs approach). Through this approach, poverty is seen as an inability on the economic side to meet the basic needs of food and non-food measured from the expenditure side. The poor are residents who have an average per capita expenditure per month below the poverty line. At present BPS uses a poverty line limit of Rp. 401,220 per capita per month in March 2018. This figure is up 3.63\% compared to September 2017 which is Rp. 387,160 per capita per month. According to Sayogyo, poor people are households that consume less than the exchange rate of $240 \mathrm{~kg}$ of rice per year per head in rural areas or $369 \mathrm{~kg}$ of rice 
per year per head in urban areas. Based on local rice prices, the amount of expenditure in rupiah can be an indicator of the poverty line. Thus the poverty criteria according to BPS and Sayogyo are studies of the poverty level of rice farmer households by calculating the level of income and feasibility of rice farming in one year and calculating the amount of rice consumption based on the amount of farm income.

\section{Methods}

\subsection{Description of the study area}

This research is a qualitative research with a descriptive format to explain, summarize various conditions, various situations or various variables that arise in the community that are the object of research based on what happens by analyzing quantitative data. Descriptive format can be done through survey research by generalizing social phenomena or certain social variables to social phenomena or social variables with a larger population [18].

This research was conducted in the village of Dolago determined purposively, with the consideration that Dolago Village is one of the villages in South Parigi District, Parigi Moutong Regency, Central Sulawesi Province, Indonesia which is dominated by the food crop agriculture sector, where the majority of the population are rice farmers. Determination of the number of respondents carried out by purposive method in 1 farmer group with 35 farmers with a land of ownership of rice farming between 0.5 - 1.5 hectares, shown in Figure 2.

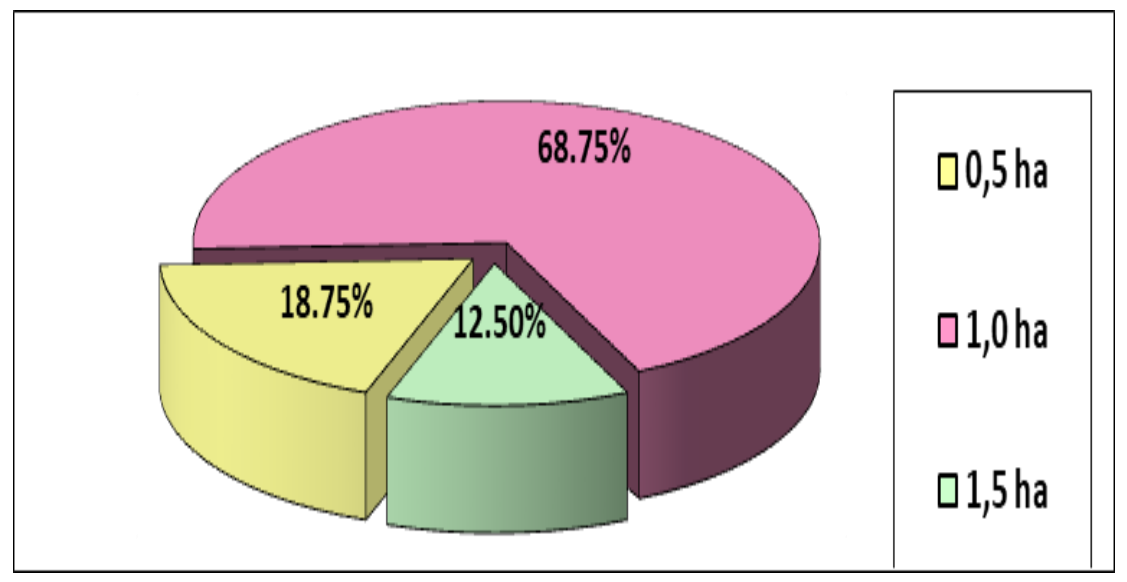

Figure 2 Land area of rice farmers in the Dolago Village

\subsection{Procedure of Research}

The procedure of research is carried out through several stages which are presented in Figure 3 below.

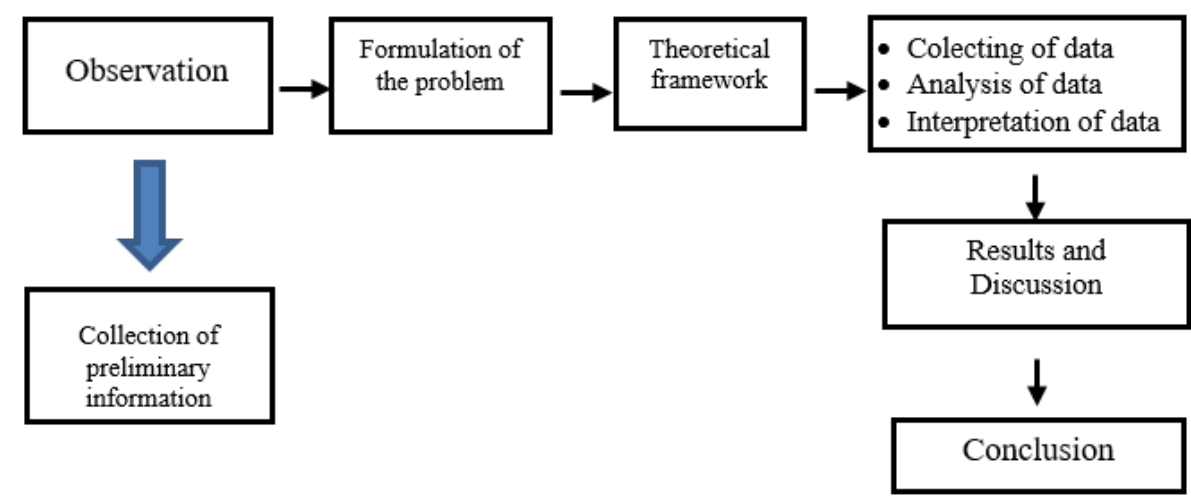

Figure 3 Procedure of research [19] 


\subsection{Analysis of data}

\subsubsection{Analysis of farm feasibility}

Calculations are carried out using descriptive methods to determine the level of profitability and feasibility of farming based on the formula of Farming Acceptance Structure as follows:

$\mathrm{I}=\mathrm{TR}-\mathrm{TC}$

$\mathrm{I}=$ Income/Provit

$\mathrm{TR}=$ Total Revenue

$\mathrm{TC}=$ Total Cost

$\mathrm{TR}=\mathrm{Y} \cdot \mathrm{Py}$

$\mathrm{TR}=$ Total Revenue

$\mathrm{Y}=$ Yields

Py $=$ Price of Yields

$\mathrm{TC}=\mathrm{FC}+\mathrm{VC}$

$\mathrm{TC}=$ Total Cost

$\mathrm{FC}=$ Fixed Cost

$\mathrm{VC}=$ Variable Cost

The analysis of farming profits was then continued with the Cost of Ratio $(\mathrm{R} / \mathrm{C})$ analysis to find out the farming feasibility index, which is an analysis by comparing farm income with the total farming costs [20]. This analysis uses the equation model as follows:

$\mathrm{RC}=\mathrm{TR} / \mathrm{TC}$

$\mathrm{R} / \mathrm{C}=$ Index of Farming Feasibility

$\mathrm{TR}=$ Total Revenue

$\mathrm{TC}=$ Total Cost

With the criteria, if:

$\mathrm{R} / \mathrm{C}=1$, farming is not profitable and does not lose /break even point

$\mathrm{R} / \mathrm{C}<1$, the farm is lost

$\mathrm{R} / \mathrm{C}>1$, farming is profitable.

2.3.2. Analysis of poverty level of farmer households

For the following research purposes, the calculation of poverty levels according to uses the equivalent consumption level of rice per capita as an indicator of poverty in rural and urban areas.

Calculating the amount of rice farmers income for one year is equal to the amount of rice obtained based on the local rice price level, with the formula: 
Amount of Rice $(\mathrm{kg})=\frac{\text { Income (IDR) }}{\text { Rice Price (IDR) }}$

Divide the amount of rice obtained for one year by the number of lives that are dependent by rice farming families, with the formula:

Kg of Rice/Person/Year $=\frac{\text { Amount of Rice }(\mathrm{kg})}{\text { Number of Family Dependent (Person) }}$

Comparing the number of $\mathrm{kg}$ of rice/person/year with the poverty line criteria to determine the poverty level of rice farmer household, with the criteria as listed in Table 1:

Table 1 Criteria for poverty levels equivalent to rice consumption according to Sayogyo [21]

\begin{tabular}{lll}
\hline Criteria & Rural (Kg/Person/Year) & Urban (Kg/Person/Year) \\
\hline Destitute & 180 & 270 \\
Very Poor & 240 & 360 \\
Poor & 320 & 480 \\
\hline
\end{tabular}

\section{Results and discussion}

\subsection{Feasibility of farming}

Table 2 Feasibility of rice farming in 1 year

\begin{tabular}{ll}
\hline Description & Value \\
\hline Production (Rice) & $1.845 \mathrm{~kg}$ \\
Price & IDR. $9.000 / \mathrm{kg}$ \\
Total Revenue (TR) & IDR. 16.605 .000 \\
Fix Cost & \\
-Land Tax & IDR. 375.000 \\
-Depreciation of Tools & IDR. 653.500 \\
Variable Cost & \\
-Seed & IDR. 350.500 \\
-Fertilizer & IDR. 750.000 \\
-Pesticide & IDR. 320.000 \\
-Labor & IDR. 1.147 .832 \\
Total Cost (TC) & IDR. 3.596 .000 \\
Income (I = TR-TC) & IDR. 13.009 .000 \\
R/C Ratio & 1,3 \\
\hline
\end{tabular}

Rice farmer revenue in a year is IDR. 16,605,000, with a production cost of IDR. 3,596,000. Thus, rice farmer income is IDR. $13,009,000 /$ year or IDR. $1,084,083$ /month. While the feasibility of rice farming is 1.3 , which means that the production cost is IDR. 1,000,000 will generate revenue of IDR. 2,400,000. Most of the rice farmers in the study location had an area of 0.5 ha $(68.75 \%)$, whereas with this land area, the rice farms managed by farmers were in breakeven. 
Based on 2013 Agriculture Census data, the number of agricultural business households in Indonesia is 26.14 million and in the food crops sub-sector there are 17.73 million households. The number of small peasant households is 14.25 million households (55.33\%) of agricultural land-use households. Meanwhile, according to the 2018 Inter Census Agriculture Survey which aims to bridge the 2013 Agriculture Census and 2023 Agricultural Census data to come, the number of agricultural business households in Indonesia is 27.22 million households [22. 23]. The majority are in rural areas with smallholder households who control less than 0.50 ha of land, totaling 16.26 million farmers households $(59.74 \%)$ of the total number of farmers households. Furthermore, from the total number of small peasant households, as many as 9.87 million peasant households $(60.70 \%)$ are rice farmers. This causes most structured farmers, especially rice farmers in Indonesia, to remain poor. On the other hand, the role of rice in the national economy has placed rice as the first largest contributor to Gross Domestic Product (GDP) in the food crops sub-sector [24].

The low income of rice farming is influenced by the amount of revenue and production costs. In order to increase income, farmers are expected to be able to increase productivity and reduce production costs [25]. Rice productivity can be increased and production costs can be minimized through efficiency in the use of inputs or factors of production, when the production input is efficient, it will affect the addition of the optimal value of acceptance for every 1 unit of production input [26.27]. The inefficient use of production inputs in the form of fertilizers, seeds, pesticides and labor that is not in accordance with the recommendations is due to limited business capital. In addition, the efficiency of distribution, marketing and price of rice as well as institutional capacity of farmers also influence efforts to increase income and feasibility of rice farming.

\subsection{Poverty level of farmers households}

The poverty level of rice farmer household is calculated based on the equivalent value of rice consumption, through the stages of analysis:

Calculating the amount of rice farmer household income for one year is equal to the amount of rice obtained based on the local rice price level (IDR. 9,000/kg), which applies at the study site:

$$
\begin{aligned}
\text { Amount of Rice (kg) } & =\frac{\text { IDR.13.009.000 }}{\text { IDR. } 9.000} \\
& =1.445,4 \mathrm{~kg}
\end{aligned}
$$

Divide the amount of rice obtained during the year by the number of people who are the dependent of rice farmer family:

$$
\begin{aligned}
\text { Kg of Rice } / \text { Person } / \text { Year } & =\frac{1.445,4 \mathrm{~kg}}{5 \text { Person }} \\
& =289,1 \mathrm{~kg} \text { Rice } / \text { Person } / \text { Year }
\end{aligned}
$$

Based on the poverty level criteria which are equivalent to the level of rice consumption, it shows that the household income of farmer from rice farming in a year is IDR. 13,009,000. The number of dependents on farm families is 5 people on average, so the equivalent needs of rice for each family member is $289.1 \mathrm{~kg}$ rice/person/year. If the farmer household income only comes from rice farming, the average rice farmer household in Dolago Village, South Parigi District, Parigi Moutong Regency is within the criteria of "Very Poor" and "Poor" households, with farmer household income is equivalent to the value between $240-320 \mathrm{~kg}$ of rice person/year.

Most farmers in rural areas are small farmers with low income, which is relatively difficult to meet food needs from economic access. An increase in food prices will increase the cost of living, especially for low-income households with a high portion of food consumption. This condition can cause food insecurity in most farming families in rural areas. This is in line, agricultural economic development has not created empowered farmers [28. 29]. The problem of agricultural economic development related to the scarcity of resources, especially the decrease in the quality and quantity of agricultural land resources, farmers resource weaknesses to adopting technologies and innovations that affect productivity, inefficiency, lack of access to business services, especially those that affect farmers in financing their agricultural business so that the productivity achieved is still below potential productivity [30]. Therefore, the empowerment of farmer organizations also plays an important role in rural communities, supporting democratic decision-making processes, leadership development and education [31]. 


\section{Conclusion}

The feasibility value of rice farming that is greater than 1 indicates that rice farming is feasible to be cultivated with additional income greater than additional costs. However, this value still places rice farming households in the criteria between "Very Poor" and "Poor" households. Farmers need government policies to support increased production, create added value, efficiency and stability in both production and consumption prices.

\section{Compliance with ethical standards}

\section{Acknowledgments}

Special thanks to Prof. Marhawati Mappatoba for her helps with opinions and comments about poverty in the agricultural food crop sector in rural areas.

\section{Disclosure of conflict of interest}

The author declares no conflict of interest.

\section{References}

[1] Müller F. (2017). Sustainable Development Goals (SDGs). PERIPHERIE - Politik • Ökonomie • Kultur, 3, 507-510.

[2] Ishartono and Raharjo TS. (2015). Sustainable Development Goals (SDGs) dan pengentasan kemiskinan. Social Work Jurnal, 0042, 159-167.

[3] Suryawati C. (2005). Memahami kemiskinan secara multidimensional. Jurnal Manajemen Pelayanan Kesehatan, 8(03), 121-129.

[4] Gonner C, Cahyat A, Haug M and Limberg G. (2015). Poverty, local government, decentralization, forests, rural communities, natural resources, wellbeing in East Kalimantan, Indonesia.

[5] Food and Agriculture Organization of the United Nations. (2017). The future of food and agriculture: trends and challenges. In The future of food and agriculture: trends and challenges.

[6] Nurwati N. (2008). Kemiskianan : model pengukuran dan alternatif kebijakan. Jurnal Kependudukan Padjajaran, $10(1), 1-11$.

[7] Chambers R. (1995). Poverty and livelihoods: whose reality counts? environment \& urbanization, 7(1), 173-204.

[8] Carter MR and Barrett CB. (2006). The economics of poverty traps and persistent poverty: An asset- based approach. Journal of Development Studies, 42(2), 178-199.

[9] Christiaensen L, Demery L and Kuhl J. (2011). The (evolving) role of agriculture in poverty reduction-an empirical perspective. Journal of Development Economics, 96(2), 239-254.

[10] Jonadi A. (2012). Analisis pertumbuhan ekonomi dan kemiskinan di Indonesia. Jurnal Kajian Ekonomi.

[11] Badan Pusat Statistik (BPS). (2019). Pendataan sosial ekonomi tahun 2018. Jakarta: Badan Pusat Statistik.

[12] Suryahadi A, Suryadarma D and Sumarto S. (2009). The effects of location and sectoral components of economic growth on poverty: Evidence from Indonesia. Journal of Development Economics, 89(1), 109-117.

[13] Anríquez G and Stamoulis K. (2007). Rural development and poverty reduction : is agriculture still the key? Journal of Agricultural and Development Economics, 4(1), 5-46.

[14] Jumiyati S, Rajindra R, Arsyad M, Pulubuhu DAT and Hadid A. (2019). Strategy of agrarian-forestry crisis management: participation, collaboration, and conflict. IOP Conference Series: Earth and Environmental Science, 235(1).

[15] Rashid MR and Dainuri MS. (2013). Food and livelihood security of the Malaysian paddy farmers. Economic and Technology Management Review, 8, 59-69.

[16] Dao MQ. (2009). Poverty, income distribution, and agriculture in developing countries. Journal of Economic Studies, 36(2), 168-183. 
[17] Creswell JW. (2016). Research design (pendekatan metode kualitatif, kuantitatif dan campuran. Yogyakarta, Pustaka Pelajar.

[18] Hasan MI. (2002). Pokok-pokok materi metodologi penelitian dan aplikasinya. Bogor, Indonesia, Ghalia.

[19] Soekartawi (2002). Prinsip dasar ekonomi pertanian: teori dan aplikasi. Jakarta, Indonesia, PT RajaGrafindo Persada.

[20] Sajogyo and Sajogyo P. (1999). Sosiologi pedesaan. Yogyakarta, Indonesia, Gadjah Mada University Press.

[21] Badan Pusat Statistik (BPS). (2013). Laporan hasil sensus pertanian 2013. Jakarta: Badan Pusat Statistik.

[22] Badan Pusat Statistik (BPS). (2018). Laporan survey pertanian antar sensus (SUTAS 2018) Jakarta: Badan Pusat Statistik.

[23] Perkasa I. (2016). Analisis pendapatan usahatani dan pemasaran serta persepsi masyarakat terhadap beras organik dan anorganik (studi kasus Kabupaten Cianjur). (Skripsi).

[24] Lumintang F. (2013). Analisis pendapatan petani padi di Desa Teep Kecamatan Langowan Timur. Jurnal Riset Ekonomi, Manajemen, Bisnis Dan Akuntansi, 1(3), 991-998.

[25] Gultom L, Winandi R and Jahroh S. (2016). Analisis efisiensi teknis usahatani padi semi organik di Kecamatan Cigombong, Bogor. Informatika Pertanian, 23(1), 7-18.

[26] Jumiyati S, Rajindra R, Tenriawaru AN, Hadid A and Darwis D. (2017). Sustainable land management and added value enhancement of agricultural superior commodities. International Journal of Agriculture System.

[27] Diao X, Hazell P and Thurlow J. (2010). The role of agriculture in African development. World Development.

[28] Aminah S, Lubis D and Susanto D. (2015). Strategi peningkatan keberdayaan petani kecil menuju ketahanan pangan. Sosiohumaniora, 18(3), 253-261.

[29] Jumiyati S, Arsyad M, Rajindra, Pulubuhu DAT and Hadid A. (2018). Cocoa based agroforestry: an economic perspective in resource scarcity conflict era. IOP Conference Series: Earth and Environmental Science, 157(1).

[30] Nurliza DE and Suryadi UE. (2019). Farmers' organizations model of independent smallholders in sustainable palm oil certification. Pertanika J. Soc. Sci. \& Hum, 27 (3), 1843 -1863.

\section{How to cite this article}

Jumiyati S. (2019). Poverty level of farmers based on total income and feasibility of rice farming. World Journal of Advanced Research and Reviews, 4(2), 82-89. 